DOI https://doi.org/10.18551/rjoas.2017-04.06

\title{
TRANSFORMATIONAL LEADERSHIP STYLE AND COMPETENCY INFLUENCE ON EMPLOYEE PERFORMANCE: STUDY OF BNI MAKASSAR BRANCH
}

\author{
Wahid Muhsin ${ }^{1,2 *}$, Salim Ubud ${ }^{2}$, Sudiro Achmad ${ }^{2}$ \\ ${ }^{1}$ Unversity of Muslim, Indonesia \\ ${ }^{2}$ Faculty of Economics and Business, University of Brawijaya, Indonesia \\ *E-mail: muhsin.wahid@yahoo.com
}

\begin{abstract}
This research aimed to examine and empirically prove transformational leadership style and competency influence work performance. This research is an explanatory research aimed to describe causal relationship between variables utilizing quantitative approach. Research population is 129 Frontliner employees (Customer services, teller) at BNI Makassar branch. Samples were determined using census method by selecting samples from total population. Research period started in 2015 to 2016 . Analysis method used to examine hypothesis is SEM. It was found that competency had positive influence yet was not significant to work performance. Competency had positive influence and was significant to transformational leadership style. Leadership style had positive influence and was significant to work performance.
\end{abstract}

\section{KEY WORDS}

Competency, transformational leadership style, performance.

An organization's success is determined by performance. Performance is derived from "to perform" which means to conduct an activity and to improve in accordance with respective responsibility in achieving predetermined objective. Performance is called "achievement" in English, but as it was derived from "to achieve" which means to attain. Therefore in Indonesian language it is often meant "menjadi pencapaian or apa yang dicapai" (to achieve or attained achievement). Performance is endeavor aimed at objective which depends on achievements in an activity (Stuggart, 2005).

Great employee performance is based on team and organization performance. They are capable of motivating others (Leskiw and Parbudyal, 2007; Yukl 2007). The most important aspect in an organization is leadership style which takes responsibility on employee to attain organization objectives (Hamilton and Cynthia, 2005).

$\mathrm{BNI}$ as banking institution possess vision to be an excellent renowned bank, leading in service and performance. BNI missions are as follows: (1) Provide prime and solutions with added value to every clients and as major partner (2) Increase investment value superior to investors, (3) Creating best open conditions as prideful place of career, (4) To be reference in implementing compliance and good company governance.

In order to realize aforementioned vision and missions, BNI requires human capitals possessing high integrity, reliable, trustworthy, disciplined, and dedicated. As a company backbone, BNI cares about increasing employee quality. Structuring, refining, and improvement should be directed towards improving human resources quality. Therefore they would be able to utilize existing opportunity, cope with incoming threats, and turn the threats to increase employee productivity in order to support performance achievements.

$\mathrm{BNI}$ possess work culture dubbed as 46 principles, which guides $\mathrm{BNI}$ individual behaviors. It consists of 4 (four) work culture: professional, integrity, customer orientation, and constant improvement. Six prime behavior ought to be possessed by BNI individuals are as follows: (1) Increase competency and provide the best result, (2) Honest, sincere, and honorable (3) Disciplined, consistent, and responsible (4) Provide the best service through synergic partnership (5) Constantly perform improvement (6) Creative and innovative. 
According to Hetami (2008), human resources in banking sector needs to be maintained professionally as to create balance between employees' need, organization demand and capability (banking). Performance appraisal consist of various integrated elements and formed by company culture using policies and procedures.

Competency influences performance. Robbins (2007) stated that human resources and competency became human resources requirement in obtaining achievement. It is required to increase performance. Human resource may achieve and fulfill performance objective in an organization. Banham (2005) stated that competency and accomplishment influence each other in achieving an objective. Thierauf (2008) explained that comprehension on individual competency is related to work theory. This theory explained that each professions require competent people acting in unison in order to produce work assessment.

Empirical study conducted by Abidin (2010) regarding employee competency on Malaysian private service sector employee performance. Samples taken were 1136 employees consisted of employees and managers from three services sub-sector. The subsectors are: education, hygiene, and technology information in Selangor. Data was obtained from Kuala Lumpur, Penang, and Johor federal region. Study exhibits that competency possess significant influence on performance. Empirical study conducted by Sulaiman et al. (2013) and Setyaningdyahet al. (2013) examined competency influence on performance. Their research was aimed to analyze competency influence on performance. Research result exhibits competency possesses positive and significant influence on performance. Mukhhopadhyay(2011); June and Mahmood(2011) conducted a study on employee performance competence influence. Their research explored logistics in Taiwan. Survey was conducted on 1,200 manufacturers to examine relationship between competence and employee performance. Researchers utilized acceleratory analysis factor and structural equation modeling techniques. Research result exhibited competence significantly affects performance.

Empirical study inconsistencies in Dubey and Ali (2011) research regarding competency influence on performance exhibits that competency does not influence performance. This research did not describe the reason why employee competency do not influence performance. Nevertheless there are few manufacture companies in India which was awarded with Excellence Award for total management practice in increasing work productivity.

Transformational leadership is based on follower development. A leader improve and direct followers' potential and ability to achieve and even surpass organization objectives. Dvir (2002).

Competency relationship to transformational leadership style is supported by quality orientation theory stated by Stonner (2007). He explained competency interpretation stating that each competent individual are related to quality orientation. More work challenges increases opportunity in realizing quality orientation. Quality orientation theory is related to individual problems.

Fatokun et al. (2010) and Hoggerst (2011) research found that competency which influenced positively and significant to transformational leadership style. Research findings described that better competency level increases transformational leadership. Study conducted by Hersond (2010), Larry (2010), and Madiock (2008) on competency influence on transformational leadership was aimed to analyze competence influence to leadership. Research result exhibits competency influenced positively and significantly to transformational leadership. Research findings described better competency increases transformational leadership. Inconsistencies were exhibited in South African Parastatal Organisation research regarding competency influence on leadership. Research result exhibited competency influenced negatively and was not significant to leadership. Ahmad (2012) and Junus (2009) research regarding competency influence on leadership exhibited that competency influenced negatively and was not significant to leadership. A leader's ability in mobilizing and empowering employees will affect employee performance. Leader behavior possesses significant impact on employee attitude, behavior and performance. Leader effectiveness is influenced by followers characteristics associated with communication 
process occurs between leaders and subordinates. Leader does not succeed if they are incapable to motivate, stimulate and satisfy employees at particular assignment and environment. Leader's task is to encourage subordinates in order to have competence and growth in anticipation of any challenges and work opportunities (Barryand Derek, 1993)

Effective leadership model is capable of providing solution in understanding leaders with large influence to their subordinate. Transformational leadership model is capable of generating successful performances for organizations, encouraging their continual success. This leadership model aims to encourage extra effort from employee's side in achieving expected high performance level (Bass, in Diety 2010)

The result of a performance is performance assessment. Stevent and Golt (2008) stated that performance is assessed by achievement benefits. A performance is judged based on activities effectively. Effectiveness of work is the result of performance assessment. Benefit theory put forward by Gunda dan Loury (2006) states that performance is the result of work benefit. The greater the benefits of carried out activities, it indicates performance achievement.

Previous empirical studies exhibits transformational leadership model influence on employee performance. Salman et al. (2011) found significant influence of transformational leadership to performance. Timothy's (2011) empirical study exhibits better transformational leadership model increases performance. A research was conducted on leadership model to employee research, by surveying smallholder companies in Ikosi Lagos, Nigeria. The researched aimed to examine leadership model influence to employee performance in smallholder companies. Research result exhibits that leadership model influenced positively and significantly to employee performance. Transformational leadership model had positive influence but was not significant to performance. Empirical study concluded leadership model is more appropriate to be utilized to encourage employee performance in smallholder companies compared to transformational leadership model. Empirical study conducted by Raja and Palanichamy (2011) on transformational leadership model influence on performance stated that transformational leadership influenced significantly to performance. Riaz et al. (2013) found transformational leadership influenced employee performance.

Konsten empirical study in transformational leadership style influence to performance based on Ogbonna and Lloyd (2000) research result, stated that leadership style does not possess significant relationship to employee performance. Empirical studies conducted by Littrel (2008) on transformational leadership style influence to performance. Research results exhibits that transformational leadership style possess indirect negative relationship and no significant effect on performance. Another empirical study finding differs from Hersey and Blanchard (2009) which states that not all leadership styles applied by managers in performing activity possess similar effect on corporate objectives achievements. Inappropriate leadership style reduce employee performance.

BNI bank as profit organization has not maximally increased related service performance by applying management. Its implementation had not been realized as occurred in BNI Makassar. Applied human resources management has not empowered the organization. BNI Makassar currently have endeavored improving human resources by improving employee performance. Performance assessment was conducted using form determined and implemented using CMO UNIT centralized computerization system.

Research Problem. Based on background above, examined research problem could be described as follows:

1. Does competency influence significantly to employee performance in BNI Bank Makassar Branch?

2. Does competency influence significantly to transformational leadership style in $B N$ Bank Makassar branch?

3. Does leadership style influence employee performance in BNI Bank Makassar Branch?

Research Objectives:

1. Examine and analyze competency influence to performance

2. Examine and analyze competency influence to transformational leadership style 
3. Examine and analyze transformational leadership style to performance

Research Significance:

1. Contribute to development of science and human resource management, particularly in relation to competence theory, transformational leadership style, and performance

2. Develop a theory to test empirically relationship between competence, transformational leadership style, and performance.

3. As the material to support future research which can be continued and developed in a similar and relevant study or research

Practical Significance:

1. Contribute to Bank BNI management in an effort to improve employee performance, and determining strategies in implementing competency, transformational leadership style, and performance.

2. Contribute input for BNI leadership in formulating policies concerning competence, transformational leadership style, and performance.

3. Provide a major contribution as a material for subsequent studies and comparative material on competency, transformational leadership style, and performance.

\section{THEORETICAL REVIEW}

Competence. There are several theories that are utilized to understand an individual's competence in the concept of human resource management. The supporting theories are as follows: labor theory, dynamic theory, quality orientation theory, problem solving theory, team theory, independence theory, creation theory, theory of integrated capabilities, asset theory, and window theory.

Theory supporting competencies relation to performance according to Thierauf (2008), argued that individual competence is linked to labor theory. This theory explains that every job requires people who are competent in their field. This means work activities and competencies are united into single unit to produce an work assessment. Understanding the labor theory mentioned above, is relevant to dynamic theory put forward by Rothwell (2006). This theory explains that human possess dynamic behavior and actions to be diligent and lazy.Typically individuals who possess diligence means having high labor dynamics potential. On the other hand, a person with laziness level possesses low dynamic level. Labor dynamics is a decisive change that determines one's potential whether they possess desire in a work activity.

Human resources competence theory, known asDonald et al. (2008) window theory, suggests that access to self-development is basically an introduction to human resource competence. It is conducted by introducing a concept stating every self-development of human beings are observed or viewed from four integrated viewpoints: Knowledge, Skill, Experience, and Attitude.

Described theory above is called windows theory from Donald et al. (2008) with KSEA concept (Knowledge, Skill, Experience, and Attitude). Window theory focus or core is reliable human resource competence. It describes a person who possesses knowledge and skills. Human resources capability is skilled people who possess adequate work experience. Experienced human resources possess good attitude. These would be potential human resources. Likewise, human resources with good attitude possessing multi-discipline knowledge will be an intelligent human resource.

Transformational Leadership Style. Leadership based on Stogdill (in Usman, 2011) is a leader became limelight through: (1) group focus; (2) acceptance of one's personality; (3) art of influencing behavior; (4) tool to influence behavior; (5) act of behavior; (6) form of doctrine (persuasive); (7) strong relationship form; (8) means to an end; (9) result of interaction; (10) differential role (11) structure creator.

Whereas according to Bush, leadership (in Usman, 2011) is "I mean the influencing others actions in achieving desirable ends". Leadership is to influence the actions of others to achieve the expected end. Leadership is method to articulate the vision, to realize the value and creating an environment in order to achieve something (Yukl, 2007) 
There are a number of reasons why leaders are required in an organization:

a. Based on genetic theory, Leader is born not made. It meant someone became a leader due to their talent.

b. Based on social theory, Leader is made not born. It meant someone could become a leader should they were educated and possess experience.

c. Based on ecology theory, a person could rise as a leader should they possess talent. The talent is improved through education and experience.

In order to understand the birth of leadership theory, its development is described as follows:

1. Leadership theory development was initiated by character theory, followed by behavior and situation theory.

2. According to character theory: (a) A leader possess advantage in form of character perceived by subordinates; (b) The characters are skills, memory, imagination, faith, and honesty; (c) Advantage strengthen their charisma which maintain loyalty, and (d) Leaders became an example, his behavior became example to others.P

3. Leadership according to behavior theory could be understood from IOWA, OHIO, and Michiga University research results.

Various empirical studies on organizational behavior, especially on leadership have been conducted. Historical studies on leadership is described in the following sections: including IOWA studies, Ohio empirical studies, and Michigan study which have become the basis for further leadership theories on classic, traditional, and modern leadership theory (Luthans, 2006).

Leadership style implies as an embodiment leader behavior, which concerns his ability to lead. The embodiments usually form a pattern or shape. Understanding such leadership style is consistent with the views expressed by Davis and Newstrom (1995) both claimed overall leader action patterns is perceived or driven by subordinates. It is known as leadership style.

Reason of leadership style rise according to Hersey and Blanchard (2009) expressed leadership style is basically a manifestation of three components. Those are the leader himself, subordinates, and situation where leadership process are realized.Hersey and Blanchard (2009) proposed that leadership style (k) is a function of leadership (p), subordinate (b) and specific situation (s) which can be denoted as: $k=f(p, b, s)$.

Leadership style based on Avolioand Bass (1994) view, stated that this theory is a powerful North America notion and principles on leadership style. This theory is one of famous theory in the last two decades and became the basis of one of these assumptions. Until recently supporters always assume that leadership style model can be accepted and used worldwide or universally. In effective leaders behavior approach, such Fiedler's (1967) contingency or Hersey and Blanchard (2009) situational leadership theory, leadership styles adapted to subordinates conditions. Leaders diagnose subordinate circumstances. Based on the conclusion a leader used leadership stylein accordance with subordinate's condition. Transactional and transformational leadership endeavor to change a leader's subordinate and encourage they to work harder in order to achieve higher performance and quality.

The interaction between leaders and employees is marked by leader's influence to change employee behavior. They will become capable, motivated and seeks to achieve high performance and quality. Leader change their employee, therefore organizational goals can be achieved together. Aspects of transformational leadership are:

Transformational process could be observed through leadership behavior such as: charismas attribute, idealized influence, inspirational motivation, intellectual stimulation, and individualized consideration. In short, Avolioand Bass (1994) describes behavior as follows:

1. Idealized influence:

This leader type influence subordinates through direct communication by emphasizing the importance of values, assumptions, commitments and beliefs, possessing determination to achieve the goal, always consider the consequences of moral and ethics of any decision made. They showed confidence in the ideals, beliefs, and values of life. Its impact is being admired, trusted, valued, and subordinates tried to identify themselves with him. 


\section{Inspirational motivation:}

Transformational leaders behave in a way to motivate and inspire subordinates by providing meaning and challenge to subordinate assignments. Subordinates are given opportunities to participate optimally in terms of ideas. Provide vision regarding organizations' promising future with clear and transparent expectations. Its influence is increase team spirit. Enthusiasm and optimism are sacrificed, therefore their will are important and valuable. It needs to be realized through high commitment.

3. Intellectual stimulation:

Leaders encourage subordinates to rethink how seek new method in conducting an assignment. Subordinates felt their leader accept and support their modus operandi, looking for new method to accomplish their assignment, and felt discovering newmethod to speed up their assignments.

4. Individualized consideration:

Leaders provide personal attention to his subordinates, such as to treat them as a whole person and appreciate their caring attitude towards the organization. The influence on subordinates, among others, to feel cared for and treated humanely from his superiors.

Based on these descriptions, it can be concluded that transformational leadership is leader's ability in working with or through others to optimally transform the organization's resources in order to achieve the objectives. Therefore researchers refer to factors which will affect transformational leadership style as idealistic Influence, Inspirational Motivation, intellectual stimulus, and individual consideration.

Performance. Performance concept is similar to work achievement concept interpretation. Assessing work achievement means assessing performance. Performance, according ro Rivai (2004) is derived from "to perform" with view entries and its respective meanings:

1. Produce, achieve, target, and activity optimization (to result, achieve, targeting, evalution);

2. To conduct or carry out(to do or carry out execute);

3. To fulfill or conduct a responsibility (to discharge of fulfill, as vow);

4. To undertake and improve a responsibility (to execute of complete an undertaking);

5. To perform what is expected by a person or machine (to do what is exepected of a person or machine).

Based on the understanding that performance is essentially defined as outcomes. There are several theories that form the basis for understanding performance which is described as follows:

1. Dual Function Theory, Algredo (2007).Performance is work achievement possessing multi effect which provides added value. Multi effect is adapted to achieve function generally known as added value and double value.

2. Optimization Theory, Douglas in Winardi (2005). Performance is achieved result utilizing individual and organization potency.

3. Assessment Theory, Nelson (2007). Performance assessment is divided into three: individual, activity, and organization performance. Individual performance is work achievement accumulation based on a person's achieved competency. Activity performance is a chain of activities started from input, process, output, outcome, benefit, and impact. Organization performance is a chain of activity which produce work value in the manner of quantity, quality, efficiency, effectiveness, and loyalty.

Theories above are in accordance to Gibsons et al. (2003) view which stated performance refers to success level in conducting assignment. Skills required to achieve predetermined objectives. A good and successful performance occurs should predetermined objectives could be achieved well according to assessment. Achieving predetermined objectives is individual performance benchmark.

Previous Research. Halorand (2009) empirical study regarding competency influence on performance exhibits competence influence positively and significant to performance. Research result exhibits better competence increases employee performance. 
Greenberg (2008) empirical study regarding competence influence on performance exhibits competence possess positive influence and significant to performance. Research result exhibits better competence increases performance.

Empiric study explained that competence strongly influence and significant to performance. Better competition increase performance.

Research conducted by Fatokun et al. (2010) and Hoggerst (2011) found that competence possess positive and significant influence on the transformational leadership. Research findings indicate that better competency increase transformational leadership. Hersond (2010), Larry (2010), and Madioc (2008) investigated the effect of transformational leadership which aimed to analyze competence influence on leadership. Result exhibited competence influenced positively and significant to transformasional leadership. Research findings exhibit better competence increases transformational leadership.

Empirical studies conducted by Inness et al. (2010), proved direct connection as well as a positive and significant correlation between transformational leadership style to performance. Its results are aimed at human resource development strategy synergy.Empirical study conducted by Timothy (2011) examined the effect of Transformational Leadership on performance. Empiric transformational leadership stylevariable has direct relationship, and correlated positively and significantly performance. It directs the leaders to provide example to subordinates they lead.

Empirical studies conducted by Salman et al. (2011) examining Influence of transformational leadership on employee performance. This study aimed to analyze influence of transformational leadership on performance. The data analysis technique used is descriptive analysis, factor analysis, (track path analysis). Research results exhibits: 1) Leadership transformational had influenced performance, based on 4 research indicators: idealistic influence, inspirational motivation, intellectual stimulus, individual consideration.Each possess relationship and significant impact on performance. This study concluded that the role of a leader very influential in improving performance.

Previous research exhibits relationship between leadership and performance possess positive influence and significant to performance.

\section{CONCEPTUAL FRAMEWORK}

Conceptual framework employed in this research is an in-depth study both in terms of theory and empiric study on influence, competence, transformational leadership and employee performance. Conceptual frameworks created in problem formulation has been described previously as well as explanation of each variable and relationship patterns formed by these variables.

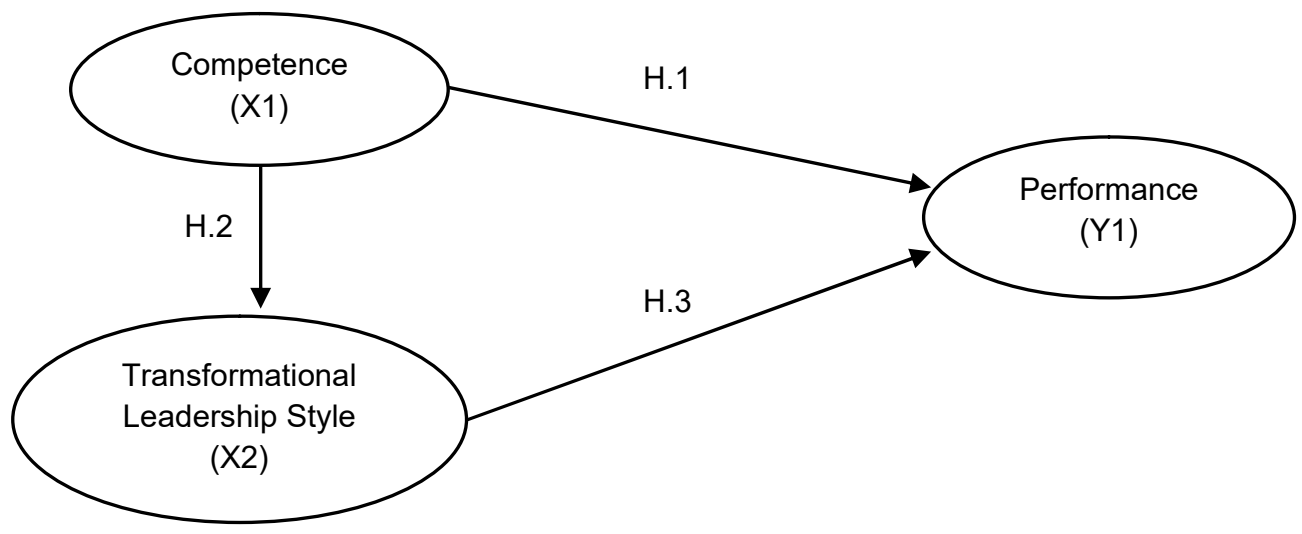

Figure 1 - Relationship between Variables 
Hypothesis:

$\mathrm{H} 1$ :Better competence increases Performance;

$\mathrm{H} 2$ :Better competence increases Transformational Leadership Style;

H3 :Better Transformational Leadership style increases performance.

\section{METHODS OF RESEARCH}

Research Approach. This research is a field research utilizing survey method through questionnaires. This research uses explanatory research approach. Data were collected at a time therefore this study could be categorized ascross section survey. Data were collected from Frontliner (Costumer services and Teller) employees working in BNI Makassar branch.

Research Location and Object. Research was conducted in BNI Makassar branch which possess 15 sub-branches.

Data Source and Type. Data type employed in this research is primary data obtained from Frontliner employees which includes Customer Service and Tellers related to competence influence towards employee performance. Primary data was obtained from respondents by distributing questionnaires. Qualitative information was obtained from selected respondents by conducting interviews regarding related variables.

Research Population and Sample. Population is generalized region consisting of subjects/objects possessing certain predetermined quality or characteristic. Population selected in this research is 129 Frontliner employee (Customer service and teller) working in BNI Makassar branch. It includes 15 sub-branches. This research could be categorized as census research as every population are utilized as sample (Sugiono, 2012).

Research Variables Operational Definition:

1. In exogenous variable model, it is known as independent variable. Exogenous variable used in this research is Competence Variable (X.1) based on Donald et al. (2008) theory. Competence is an endeavor to improve effectively and performance by integrating individual will and organization objective expansion. It is standardized by BNI 46 Makassar branch. Indicator utilized to assess employee competence is based on Donald et al. (2008) theory. It includes: Knowledge, Skills, Experience, and Attitude. Transformational Leadership Style (X.2) theory explained by Bass (2006) describes transformational leadership as determining factor which influence employee attitude, perception, behavior, and work satisfaction. In addition, it will decrease conflict often occurred in an organization which nature describes relationship process between leader and subordinates. It is based on values, beliefs, and assumptions on organization's vision and missions. Indicator utilized in assessing transformational leadership style is: Idealistic influence, inspirational motivation, individual consideration, intellectual stimuli.

2. Endogenous variable is variables predicted by one or few others variable available in the model. Endogenous employee performance variable $(\mathrm{Y} .1)$ is achieved work result attained by an employee in conducting their work according to standard and criteria determined by BNI 46 Makassar branch. Indicator utilized in assessing employee performance is based on Armstrong and Baron's (2005) Grand Theory which involves: Quantity, Quality, and Will.

\section{RESEARCH FINDINGS}

Competence Influence to Performance. The first hypothesis examination is competence influence (X.1) on performance coefficient was proven by competence direct influence on employee performance with a value of 0.043 and $p$-value $=0.648$. As $p$-value $>$ 0.05 then hypothesis stating competence possess significant positive effect on performance employee is denied. Given the coefficient is positive but insignificant it can be concluded that relationship between the two are in the same direction but could not increase employee competence. Good performance could not significantly improve employee performance. 
Competence Influence to Transformational Leadership Style. Second hypothesis examination is competence influence (X.2) to transformational leadership style. Direct influence coefficient on competency influence to transformational leadership is 0.317 with $p$ value $=0.000$. As $p$-value $<0.05$, then hypothesis that competence possess significant positive effect on transformational leadership was accepted. Given the significant coefficient is positive and may be concluded that the relationship between the two is similar and significant, in meant that higher competence will strengthen leadership style.

Transformational Leadership Style Influence to Performance. Third hypothesis examination is leadership style (X.3) influence to performance. Direct influence coefficient of transformational leadership influence on employee performance is 0.445 with $p$-value $=$ 0.002.As p-value <0.05, then hypothesis on transformational leadership possessing significant positive effect on employee performance is accepted. Considering coefficient was positive and significan, it meant relationship between the two is unidirectional and significant. Better transformational leadership style would improve employee performance.

\section{CONCLUSION}

Competency influences positively but was insignificant to performance. Competency influences positively and significant to transformational leadership style. Transformational leadership style influences positively and was significant to performance.

It is recommended for BNI Makassar Branch leaders to play an active role in providing employee competence understanding by regarding transformational leadership and employee performance. There were insignificant variables that need attention and in this study that require attention and improvement. High competence does not improve employee performance due to several factors that have not been revealed in this study such as culture and employee characteristics.

\section{REFERENCES}

1. Abidin. (2010). Impact of workers' competence on their performance in the Malaysian private service sector. BEH-Business and Economic Horizona. 2(2): 25-36.

2. Ahmad, P.A. (2012).Pengaruh Kompetensi dan Iklim Organisasi Terhadap Kinerja Karyawan Pada PT. Jasa Marga (Persero) Tbk. Cabang Belmera. Universitas Medan, Medan.

3. Armstrong, M. and Baron, A. (2005). Managing Performance: Performance Management in Action. CIPD Publishing, UK.

4. Algredo, M. (2007).Performance by Human Resource Management Handbook. Published by Ohio University Press.

5. Avolio, B.J. and Bass, B.M. (1994). Individual Consideration Viewed at Multiple Levels of Analysis : A Multilevel Framwork for Examining Te Diffusio of Transformational Leadership.Journal of Leadership Quarterly, 6(2):199-218.

6. Bass. (2006).Transformational leadership.Lawrence Elrbaun Associates, New Jersey.

7. Banham, J. (2005).Development of Human Resources Management. Published by prentice Hall, New York.

8. Barry, C. and Derek, L. (1993). Organisational Behaviour and Design, Perilaku dan Desain Organisasi. PT. Elex MediaKomputindo,Jakarta.

9. Davis, K. and Newstrom. (1995). Perilaku dalam Organisasi. Erlangga, Jakarta.

10. Diety, L.(2010). Analisis Perbedaan Kepuasan Kerja Karyawan Ditinjau Dari Gaya Kepemimpinan Transformasional dan Transaksional Pada Kantor Divisi Regional I PT. Telkom Medan. Unpublished Thesis. Universitas Sumatera Utara, Medan.

11. Donald, McEachern, Thomas.(2008). Competence of personal in Prospective Theories. Retrieved from http//www.journalhumanresoucesmanagement.com.id

12. Dubey, R. and Ali, S.S. (2011). Study on Effect of Founctional Competency on performance of indian Manufacturing Sector.Int. J. Eng. Bus.manag. 3(3): 1-15. 
13. Dvir. (2002). Impact of Transformasional Leadership on FollowerDevelopment and Performance: A Field Experiment. AMJ Pres.

14. Fatokun, J.O., Salaam, M.O. and Ajegbomogun, F.O. (2010). The Influence of Leadership Style on the Performance of Subordinates in Negerian Libraries.Library Philoshophy and Practice (e-Journal), paper 422.

15. Fiedler, F.E. (1967). A Theory of Leaderships Effectiveness. Mc Graw-Hill Book Company, New York.

16. Gunda, B. and Loury.(2006).Organizational Behavior and Design. PT. Elex Media Komputindo, Jakarta

17. Gibsons, J., Ivancevich, L.J and Donelly Jr, J.H. (2003).Organisasi Perilaku Struktur Dan Proses. Djoeban Wahid (Ed.). Binarupa Aksara, Jakarta.

18. Halorand, M. (2009). Application of Human Resources in High Performance.Journal of Human Resources, 5: 1-10.

19. Hamilton and Cynthia. (2005). Talcott Parsons dan Pemikirannya. PT. Tiara Wacana, Yogya.

20. Hersey, P. and Blanchard, K.H.(2009). Management Organizational Behavior, Utilizing Human Resources. 4 th, ED Englewood Cliffs.Prentices Hall Inc.,New Jersey.

21. Hersond, P.H. (2010).Competence And Good Recruitmen on Leadership Toward Performance. Staff in Africa Evidence From Industry survey Data, Negeria.

22. Hetami. (2008). Pengaruh Motivasi, Kemampuan dan Disiplin Terhadap Kinerja Karyawan pada Sebu ah Persero Asuransi. Universitas Mulawarman Samarinda.Jurnal Ekonomi dan Bisnis,6(2), ISSN 1426435.

23. Hoggerst, R. (2011). The Competence, Motivation and Recruitmen Satisfaction Affect Toward Performance. Australia College.

24. Inness, M., Turner, N., Barling, J. and Stride, C.B. (2010). Transformational Leadership and Employee Safety Performance A Within PersonBetween-Jobs Design.Journal of Occupational Health Psychology, 15(3): 279-290.

25. June, S. and Mahmood, R. (2011).The Relationship between Role Ambiguity, Competency and Person-job Fit With the Job Performance of Employees in the Service Sector SMEs in Malaysia. Business Management Dynamics, 1(2): 79-98.

26. Junus, Amri, 2009, Pengaruh Komitmen Individu, Organisasi dan Kepemimpinan Terhadap Kinerja Pegawai Serta Dampaknya Pada Kinerja Dinas Pengelolaan Keuangan dan Kekayaan Aceh, Jurnal Manajemen Pascasarjana Universitas Syiah Kuala, Aceh.

27. Greenberg, J. (2008).Affect of Motivation, Competence,culture toward Kepuasan dan performance and correlation with increasing Human Resource Quality. Scientific Software International Inc., Chicago.

28. Littrel, R.F. (2008). Desirable Leadership Behaviors of Multicultural Manager in China.Journal of Management Development. Volume 21.

29. Larry, C.S. (2010). Character and Serven Leadership: Ten Characteristic of Leadership styles and Subordingnate Commitmen. 15(2): 164-184.

30. Leskiw and Parbudyal, S. (2007). Leadership development: learning from best practices. Leadership and Organization Development Journal, 28(5): $444-464$.

31. Luthans, F. (2006). Perilaku Organisasi, (Alih Bahasa V.A Yuwono, dkk),Edisi Bahasa Indonesia. ANDI,Yogyakarta.

32. Madiock,P.E. (2008). The Link Between Leadership Style, Communicator competence, and Employee Satisfaction.Journal of Business Communication, Volume 45 Number 1, January 2008 61-78 DOI: 10 1177/0021043607309351@ 2008 by the Association for Business Communacation.

33. Mukhhopadhyay, K. (2011). A Competency Based Management System for Sustainableevelopmentby Innovative Organizations:A Proposal of Method and Tool. Journal of Bussiness Perspective, 15(2): 153-162. Sage Publications.

34. Nelson, N.(2007).Human Resources Management in Strength Quality Prospective. Published McGraw Hill, New York. 
35. Ogbonna, E. and Lioyd, H.C. (2000).Leadership Style, Organization Culture And Performance:Emirical Evidence from UK Companies. InternationalJournal of Human Resorces Management, 11: 766-788.

36. Robbins, S.P. (2007). Kumpulan Teori-teori Motivasi.2nd Edition. Prenhahallindo, Jakarta.

37. Rothwell, H.(2006). Planning For Good Competence Individual.Libraries Unlimited, ISBN $0-313-32155-8$

38. Rivai, V. (2004).Performance Appraisal. Sistem yang tepat untuk menilai kinerja karyawan dan meningkatkan Daya Saing Perusahaan. Rajawali Press, Jakarta

39. Raja, A. and Palanichamy, P. (2011). Leadership style and its impact onorganizational commitment. The Journal of Commerce, 3(4): 167-175. doi:10.1177/097324701100700315

40. Riaz, Ramzan, Ishaq, Akram, Karim. (2013).Transformational Leadership and Employees Career Salience; an Empirical Study Conducted on Banks of Pakistan.International Journal of Business and Social Science, 3(8): 153.

41. Salman, Zahid, Riaz, Adnan, Saifullah, Muhammad,Rasid, and Majed. (2011). Leadership Styles and Employess Performance (A Case Studi of Shakarganj Mills Limited Jhang Pakistan). Interdisciplinary Jornal of Comtemporary Research in Business, $3(6)$.

42. Setyaningdyah, E., Kertahadi, U.N. and Thoyib, A. (2013). The Effects of human Resource Competence, organisational comimitment and transactional leadership on work Dicipline job satisfaction and Employee's performance.Interdisciplinary Journal Of Contemporary Research In Business, 5(4): 140-153.

43. Stevent and Golt. 2008. Perilaku Organisasi, Edisi ke Sepuluh. Translated by Drs. Benyamin Molan. Jakarta: Salemba Empat.

44. Stuggart, T.G.(2005). Organizational performance in Behavior. Administration Science Quaterly, pp. 91-96.

45. Stonner, B. (2007).Organizational and Management. Routledge and Kegan Paul, London.

46. Sugiono.(2012). Metode Penelitian Kuantitatif Kualitatif and RND. Alfabeta,Bandung.

47. Sulaiman, W.S.W., Almsafir, M.K. and Ahmad, Z.A. (2013). Job Performance: Relationship between Competency and Sttitude towards Achieving Tnb's Vision.Journal of Advanced Social Research, 3(1): 1-11.

48. Timothy. (2011). Effects Of Leadership style on Organization performance: A Survey Of Selected Smail Scale Enterprises in Ikosi-Ketu Council Development Area Of Lagos State Nigeria. Australian Journal of Businenss and Management Research, 1(7): 100111.

49. Thierauf, F. (2008). Perpective The Compentency HRM. Harper and Row, New York.

50. Usman, H. (2011). Manajemen, Teori, Praktek, dan Riset Pendidikan. PT. Bumi Aksar, Jakarta.

51. Winardi, H.(2005).Paradigma SDM dalam Kinerja Kerja. Rineka Cipta, Jakarta.

52. Yukl, G. (2007). Kepemimpinan Dalam Organisasi. 5th Edition. Budi Suprianto (ED.). Indeks, Jakarta. 